\title{
EFFECT OF MINERAL FERTILIZATION AND CUTTING NUMBERS ON GROWTH AND PRODUCTIVITY OF GUAR PLANT I. EFFECT ON VEGETATIVE GROWTH PARAMETERS
}

\author{
M.A.H. Abdou; F.S. Badran; A.A. El-Sayed and O.R.A. Ibrahim \\ Horticulture Department, Fac. of Agric., Minia Univ. Egypt
}

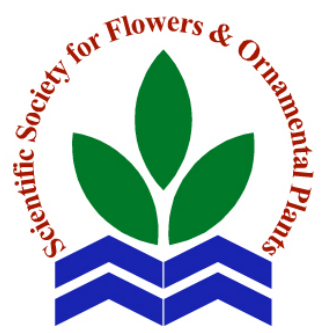

Scientific J. Flowers \& Ornamental Plants, 8(4):461-469 (2021).

Received:

$5 / 12 / 2021$

Accepted:

24/12/2021

Corresponding author: M.A.H. Abdou mahmoud.abdo@mu.edu.eg

ABSTRACT: This work was carried out during the two successive growing seasons of 2019 and 2020 at the farm of Animal Industrial Feeding Factory at Shosha Village, Production Sector, Agricultural Research Centre, Ministry of Agriculture, and Laboratory of Floriculture, Faculty of Agriculture, Minia University, to study the effect of mineral fertilization and number of cuts on the vegetative growth of guar (Cyamopsis tetragonoloba, (L.) Taub.) plants. Data revealed that increasing mineral NPK level led to a significant increase in plant height, number of branches and herb fresh and dry weights as compared with control. While, without cut treatment (control) was superior to other cutting treatments (one, two and three cuts) on increasing all studied previous parameters except number of branches. It can be noticed that the highest level of NPK mineral fertilization $(500 \mathrm{~kg} / \mathrm{fed}$ comprised of $200 \mathrm{~kg}$ ammonium sulfate + $200 \mathrm{~kg}$ calcium supper phosphate $+100 \mathrm{~kg}$ potassium sulfate) in combination with applying three cuts led to the greatest branch number.

Key words: Cyamopsis tetragonoloba, fertilization, NPK, number or cuts, vegetative growth.

\section{INTRODUCTION}

Guar, Cyamopsis tetragonoloba (L.) Taub. belongs to Family Fabaceae (Leguminosae) (Gillet, 1958), is a summer legume traditionally grown in the semi-arid regions of India and Pakistan as a vegetable, forage and grain crop. At the present time, guar is noticeable as one of the most important sources of mucilage, which makes a special type of gum, used in industry and pharmaceutical preparation. Guar seeds contain about $34 \%$ protein, $23 \%$ gum and $40 \%$ fixed oil (Kamel, 2009). There is still, however, a lack of a complete nutritive profile of guar cultivated in Egypt as summer forage legume and cut at a different time to get good branches, good yields and biomass quality and quantity are available.

Chemical nutrients, particularly N, P and $\mathrm{K}$ are most important for plants, as they play a vital role in the plant structure of several compounds i.e. hormones, protein, amino acids, nucleic acids and fats, and regulation of water relationship. However, using intense chemical fertilizers lead to serious problems on human health due to contamination of the environment (air, soil and drainage water). Supplying guar plants with $\mathrm{N}, \mathrm{P}$ and $\mathrm{K}$ fertilization led to an increase in plant height, number of branches and herb fresh and dry weights (Sortino and Gresta, 2007; Kamel, 2009; Ayub et al., 2011 and Abo El-Ezz, 2019).

Cutting number had a positive impact on the growth of different plants (Omer et al., 1993 on guar; Akash and Saoub, 2000 on sudangrass; Simon et al., 2003 on white clover; Moniruzzaman et al., 2008 on kangkong plant; Abd El-Azim and Waleed, 2016 and Singh et al., 2017 on coriander; Nayak and Maji, 2018 on palak; Ansa and Garjila, 2019 on elephant grass).

Therefore, the aim of this study was to add more information concerning the effect 
of mineral fertilization and cutting frequency on the growth of guar plants (Cyamopsis tetragonoloba (L.) Taub.).

\section{MATERIALS AND METHODS}

This work was carried out during the two successive growing seasons of 2019 and 2020 at the farm of Animal Industrial Feeding Factory, Shosha Village, which belongs to the Production Sector, Agricultural Research Centre, Ministry of Agriculture, and laboratory of Floriculture, Faculty of Agriculture, Minia University, to study the effect of mineral fertilization and number of cuts on the vegetative growth of guar (Cyamopsis tetragonoloba, (L.) Taub.) plants.

\section{Plant materials and proceedings:}

The seeds of guar plant were obtained from Ornamental Nursery, Faculty of Agriculture, Minia University. The seeds were sown in sandy calcareous soil on the first day of March in both seasons. The experimental unit (plot) was $4.8 \mathrm{~m}^{2}(2.0 \times$ 2.4 meters) and contained 3.0 rows, $50 \mathrm{~cm}$ apart, and seeds were sown in hills, $30 \mathrm{~cm}$ apart on one side of the row, therefore, each plot contained 21 hills and plants were thinned to one plant per hill after three weeks from sowing date.

\section{Experimental layout:}

This experiment was laid out as a splitplot arrangement in a randomized complete block design (RCBD) with three replicates. The main plot (A) comprised four levels of
NPK mineral fertilization $\left[\mathrm{N}_{0} \mathrm{P}_{0} \mathrm{~K}_{0}\right.$ (control), $\mathrm{N}_{1} \mathrm{P}_{1} \mathrm{~K}_{1}(125 \mathrm{~kg} / \mathrm{fed}), \mathrm{N}_{2} \mathrm{P}_{2} \mathrm{~K}_{2}(250 \mathrm{~kg} / \mathrm{fed})$ and $\left.\mathrm{N}_{3} \mathrm{P}_{3} \mathrm{~K}_{3} \quad(500 \mathrm{~kg} / \mathrm{fed})\right]$. While four treatments of number of cuts $\left[\mathrm{NC}_{0}\right.$ (without cut), $\mathrm{NC}_{1}$ (one cut), $\mathrm{NC}_{2}$ (two cuts) and $\mathrm{NC}_{3}$ (three cuts)] occupied the sub-plots. Therefore, the experiment consists of 16 treatments. The soil analysis was carried out according to the procedure of Jackson (1973) and the obtained data were shown in Table (a).

\section{Mineral fertilization treatments:}

Ammonium sulfate $(20.6 \% \mathrm{~N})$, calcium supper phosphate $\left(15.5 \% \quad \mathrm{P}_{2} \mathrm{O}_{5}\right)$ and potassium sulfate $\left(48.0 \% \mathrm{~K}_{2} \mathrm{O}\right)$ as a sources of nitrogen, phosphorus and potassium, respectively, were used to prepare the following mineral fertilizer formulations:

- $\mathrm{N}_{0} \mathrm{P}_{0} \mathrm{~K}_{0}$ (control): without fertilization.

- $\mathrm{N}_{1} \mathrm{P}_{1} \mathrm{~K}_{1}(125 \mathrm{~kg} / \mathrm{fed})$ : Comprised of $50 \mathrm{~kg}$ ammonium sulfate $+50 \mathrm{~kg}$ calcium supper phosphate $+25 \mathrm{~kg}$ potassium sulphate.

- $\mathrm{N}_{2} \mathrm{P}_{2} \mathrm{~K}_{2}(250 \mathrm{~kg} / \mathrm{fed}):$ Comprised of 100 $\mathrm{kg}$ ammonium sulphate $+100 \mathrm{~kg}$ calcium supper phosphate $+50 \mathrm{~kg}$ potassium sulphate.

- $\mathrm{N}_{3} \mathrm{P}_{3} \mathrm{~K}_{3}$ : $(500 \mathrm{~kg} / \mathrm{fed})$ : Comprised of 200 $\mathrm{kg}$ ammonium sulphate $+200 \mathrm{~kg}$ calcium supper phosphate $+100 \mathrm{~kg}$ potassium sulphate.

The amount of $\mathrm{P}$ was added during the preparation of the soil for cultivation. The amount of NK was divided into three equal

Table a. Physical and chemical analysis of the used soil during the two seasons of 2019 and 2020.

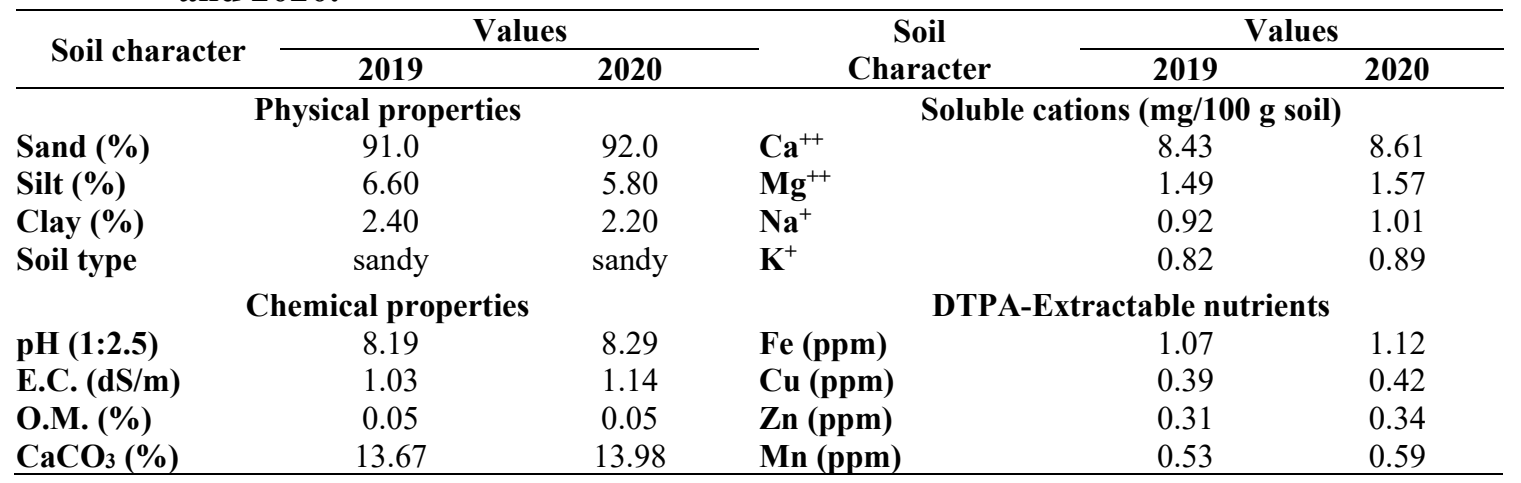


doses, the first one was done on April, $1^{\text {st }}$, the second one was done on April, $15^{\text {th }}$ and the last one was done on April, $30^{\text {th }}$.

\section{Cuttings treatments:}

- $\mathrm{NC}_{0}$ : The plants were left without cutting but they were harvested at the end of the experiment (in the first week of October) in both seasons.

- $\mathrm{NC}_{1}$ : The plants were cut one time on May, $15^{\text {th }}$ and they were harvested in the first week of October in both seasons.

- $\mathrm{NC}_{2}$ : The plants were cut two times on May, $15^{\text {th }}$ and July, $1^{\text {st }}$ and they were harvested in the first week of October in both seasons.

- $\mathrm{NC}_{3}$ : The plants were cut three times on May, $15^{\text {th }}$, July, $1^{\text {st }}$ and August, $15^{\text {th }}$ and they were harvested in the $1^{\text {st }}$ week of October in both seasons.

\section{Data recorded:}

In the first week of October of both seasons the following vegetative growth traits were collected: plant height $(\mathrm{cm})$, number of branches/plant, herb fresh and dry weights/plant (g).

\section{Statistical analysis:}

The obtained results were tabulated and statistically analyzed by using MSTAT-C (1986) software. While L.S.D. test at 5\% was followed to compare the means of treatments.

\section{RESULTS AND DISCUSSION}

\section{Plant height (cm):}

Data presented in Table (1) showed that mineral fertilization treatments significantly increased plant height $(\mathrm{cm})$ of guar (Cyamopsis tetragonoloba, (L.) Taub.) compared to control plants in both seasons. The increase in plant height over the control was $10.01,21.0$ and $33.10 \%$ due to $\mathrm{N}_{1} \mathrm{P}_{1} \mathrm{~K}_{1}$, $\mathrm{N}_{2} \mathrm{P}_{2} \mathrm{~K}_{2}$ and $\mathrm{N}_{3} \mathrm{P}_{3} \mathrm{~K}_{3}$ during the first season. The same trend was observed in the second season. So, the tallest plants (97.91 and $97.28 \mathrm{~cm}$ in both seasons, respectively) were obtained by the highest level of NPK (500 $\mathrm{kg} / \mathrm{fed}$ ).

Similar results on guar plant were noted by Razin (1991), Meawad et al. (1991), Salah El-Deen (1997), Omar (2005), Sortino and Gresta (2007), Salama and Nawar (2016), Seerangan et al. (2019) and Pimonov et al. (2021).

As can be seen from data presented in Table (1), without cut treatment $\left(\mathrm{NC}_{0}\right)$ significantly increased plant height than all other treatments [one cut $\left(\mathrm{NC}_{1}\right)$, two cuts $\left(\mathrm{NC}_{2}\right)$ or three cuts $\left.\left(\mathrm{NC}_{3}\right)\right]$ in both seasons, whereas, the shortest plants were obtained from plants grazed three times $\left(\mathrm{NC}_{3}\right)$.

Our results are in agreement with those reported by Omer et al. (1993) on guar plant; Giambalvo et al. (2011) and Tufail et al. (2020) on berseem clover; Rana et al. (2015) on fenugreek plant; Abd El-Azim and Waleed (2016), Singh et al. (2017) and Bhapkar et al. (2019) on coriander; Ibrahim (2017) on Moringa oleifera and Ansa and Garjila (2019) on elephant grass.

The interaction between the main and sub-plot treatments $(\mathrm{A} \times \mathrm{B})$ was significant for plant height in both seasons. The tallest plants were recorded with the plants fertilized with $\mathrm{N}_{3} \mathrm{P}_{3} \mathrm{~K}_{3}$ without cut (122.72 and $122.84 \mathrm{~cm}$ in both seasons, respectively) or fertilized with $\mathrm{N}_{2} \mathrm{P}_{2} \mathrm{~K}_{2}$ without cut (111.56 and $112.16 \mathrm{~cm}$ in both seasons, respectively).

\section{Number of branches/plant:}

Data presented in Table (1) proved that all used mineral fertilization treatments led to a significant increase in the number of branches/plant as compared to control plants in both seasons. The increase was parallel to the increase of mineral fertilization level. Therefore, the application of NPK (500 $\mathrm{kg} / \mathrm{fed}$ ) gave the highest value of branches number (17.19 in the first season and 15.84 branches in the second one) compared with control which recorded only 11.76 and 10.43 in the first and second seasons, respectively. 
M.A.H. Abdou et al.

Table 1. Effect of mineral fertilization, number of cuts and their interactions on plant height (cm) and number of branches of guar plants during the first and second seasons.

\begin{tabular}{|c|c|c|c|c|c|c|c|c|c|c|}
\hline \multirow{3}{*}{$\begin{array}{l}\text { Number of cuts } \\
\text { treatments } \\
\text { (B) }\end{array}$} & \multicolumn{10}{|c|}{ NPK levels (kg/fed) (A) } \\
\hline & 0.0 & 125 & 250 & 500 & $\begin{array}{c}\text { Mean } \\
\text { (B) }\end{array}$ & 0.0 & 125 & 250 & 500 & $\begin{array}{c}\text { Mean } \\
\text { (B) }\end{array}$ \\
\hline & \multicolumn{5}{|c|}{ The $1^{\text {st }}$ season (2019) } & \multicolumn{5}{|c|}{ The $2^{\text {nd }}$ season (2020) } \\
\hline & \multicolumn{10}{|c|}{ Plant height (cm) } \\
\hline Control (Witho & 92.20 & 101.42 & 111.56 & 122.72 & 106.98 & 93.50 & 102.40 & 112.16 & 122.84 & 107.73 \\
\hline One cut & 82.98 & 91.28 & 100.41 & 110.45 & 96.28 & 83.68 & & 100.38 & 109.94 & 96.41 \\
\hline Two cuts & 68.04 & 74.85 & 82.33 & 90.57 & 78 & 68 & & 81 & 89.60 & 78.58 \\
\hline Three & 51.03 & 56.14 & 61 & 67.92 & 59.21 & 50.81 & 55 & 60 & 66.75 & 58.54 \\
\hline Mean ( & 73.56 & 80.92 & 89.01 & 97.91 & & 74.05 & 81.10 & 88.82 & 97.28 & \\
\hline \multirow{2}{*}{ L.S.D. at 5\% } & \multicolumn{2}{|c|}{ A: 7.01} & B: 6.66 & \multicolumn{2}{|c|}{ AB: 13.32} & \multicolumn{2}{|c|}{ A: 7.15} & B: & \multicolumn{2}{|c|}{ AB: 12.90} \\
\hline & \multicolumn{10}{|c|}{ Number of branches/plant } \\
\hline Cont & & & 12 & 12.70 & 11.28 & 8.20 & 12.50 & & & \\
\hline One cut & 11.22 & 15.29 & 15.62 & 15.84 & 14.49 & 10.12 & 14.19 & 14.52 & 15.07 & 13.48 \\
\hline Two cuts & 13.46 & 18.17 & 18.52 & 18.98 & 17.28 & 11.16 & 15.87 & 16.45 & 16.91 & 15.09 \\
\hline Three cuts & 14.28 & 19.08 & 20.64 & 21.24 & 18.81 & 12.24 & 17.04 & 17.52 & 18.00 & 16.20 \\
\hline Mean (A) & 11.76 & 16.14 & 16.77 & 17.19 & & 10.43 & 14.90 & 15.40 & 15.84 & \\
\hline L.S.D. at 5\% & \multicolumn{2}{|c|}{ A: 0.62} & B: 0.20 & \multicolumn{2}{|c|}{ AB: 0.40} & \multicolumn{2}{|c|}{ A: 0.42} & B: 0.23 & \multicolumn{2}{|c|}{ AB: 0.46} \\
\hline
\end{tabular}

The stimulating effects of NPK fertilization on increasing branches number/plant were emphasized on guar by Ali (1990), Sortino and Gresta (2007), Kamel (2009), Mohamed (2009), Ayub et al. (2011), Gendy et al. (2013), Mahdy and ElSaid (2017) and Pimonov et al. (2021).

Regarding the impact of number of cuts on the number of branches/plant, data presented in Table (1) indicated that number of cuts had a positive significant effect on branches number/plant in both seasons. It could be observed that increasing number of cuts from $\mathrm{NC}_{0}$ to $\mathrm{NC}_{1}, \mathrm{NC}_{2}$ and $\mathrm{NC}_{3}$ led to a significant increase in the number of branches/plant. The greatest number of branches/plant was recorded with the three cutting treatments. Such increase over the control reached $28.46,53.19$ and $66.76 \%$ due to $\mathrm{NC}_{1}, \mathrm{NC}_{2}$ and $\mathrm{NC}_{3}$, respectively in the first season. The same trend was noted in the second season.

Our results are in the line with those studied by Omer et al. (1993) on guar plant, Akash and Saoub (2000) on sudangrass, Simon et al. (2003) on white clover, Moniruzzaman et al. (2008) on kangkong plant, Ventroni et al. (2010) on alfalfa, Giambalvo et al. (2011) and Tufail et al.
(2020) on berseem clover, Sowiński and Szydełko (2011) on sorghum-sudangrass hybrid, Lawal et al. (2015) and Ibrahim (2017) on Moringa oleifera, Rana et al. (2015) on fenugreek plant; Abd El-Azim and Waleed (2016) and Singh et al. (2017) on coriander.

The interaction between mineral fertilization and number of cuts $(\mathrm{A} \times \mathrm{B})$ was significant for number of branches/plant in both experimental seasons. The highest number of branches/plant was produced from plants received the highest level of mineral fertilization $\left(\mathrm{N}_{3} \mathrm{P}_{3} \mathrm{~K}_{3}\right)$ in addition to three time cuts in both seasons (21.24 and 18.00 branches/plant in both seasons, respectively).

\section{Herb fresh and dry weights/plant (g):}

Data presented in Table (2) stated that the influence of mineral fertilization treatments on herb fresh and dry weights/plant was significant in both seasons. Fertilizing plants with $\mathrm{N}_{1} \mathrm{P}_{1} \mathrm{~K}_{1}$, $\mathrm{N}_{2} \mathrm{P}_{2} \mathrm{~K}_{2}$ and $\mathrm{N}_{3} \mathrm{P}_{3} \mathrm{~K}_{3}$ increased herb fresh and dry weights/plant as compared to unfertilized plants. The heaviest herb fresh and dry weights/plant were produced as a result to applying $\quad \mathrm{N}_{3} \mathrm{P}_{3} \mathrm{~K}_{3} \quad(500 \mathrm{~kg} / \mathrm{fed})$ mineral treatment, followed by $\mathrm{N}_{2} \mathrm{P}_{2} \mathrm{~K}_{2}(250 \mathrm{~kg} / \mathrm{fed})$, 
Table 2. Effect of mineral fertilization, number of cuts and their interactions on herb fresh and dry weights/plant of guar plants during the first and second seasons.

\begin{tabular}{|c|c|c|c|c|c|c|c|c|c|c|}
\hline \multirow{3}{*}{$\begin{array}{l}\text { Number of cuts } \\
\text { treatments } \\
\text { (B) }\end{array}$} & \multicolumn{10}{|c|}{ NPK levels (kg/fed) (A) } \\
\hline & 0.0 & & 250 & 500 & $\begin{array}{c}\text { Mean } \\
\text { (B) }\end{array}$ & 0.0 & & 250 & 500 & $\begin{array}{c}\text { Mean } \\
\text { (B) }\end{array}$ \\
\hline & \multicolumn{5}{|c|}{ The $1^{\text {st }}$ season (2019) } & \multicolumn{5}{|c|}{ The $2^{\text {nd }}$ season (2020) } \\
\hline & \multicolumn{10}{|c|}{ Herb fresh weight/plant } \\
\hline Contr & 2.13 & 720.03 & 746.46 & 850.16 & 667.20 & & 729.60 & 756.00 & 859.20 & 674.73 \\
\hline One cut & 8 & 669.63 & 694.21 & 790.65 & 620 & 329.34 & 678 & 08 & 799.06 & 627.50 \\
\hline Two & 8 & 616.06 & 638.67 & 727.40 & 570 & 302 & 624.25 & 646.83 & 735.13 & 577 \\
\hline Thr & 3 & 542 & 562.03 & 640.11 & 502.35 & 266 & 549.34 & 569.21 & 646.92 & 508.02 \\
\hline Mean & 1.51 & 636.96 & 660.34 & 752.08 & & 313.27 & 645.43 & 668.78 & 760.08 & \\
\hline \multirow[t]{2}{*}{ L.S.D at $5 \%$} & \multicolumn{2}{|c|}{$\mathrm{A}: 20.38$} & B: 10.11 & \multicolumn{2}{|c|}{ AB: 20.22} & \multicolumn{2}{|c|}{ A: 21.55} & B: 12.33 & \multicolumn{2}{|c|}{ AB: 24.66} \\
\hline & \multicolumn{10}{|c|}{ Herb dry weight/plant } \\
\hline & & & & 186.06 & 139.27 & & 6 & & & \\
\hline One & & 101.84 & 165.11 & 172.11 & 128 & 79 & 173.86 & 176.77 & 182.50 & 153.06 \\
\hline Two cuts & 69.77 & 93.19 & 151.08 & 157.48 & 117. & 72.37 & 159.08 & 161.74 & 166.99 & 140.05 \\
\hline Thre & 61.05 & 81.54 & 132.19 & 137.79 & 103.14 & 63.32 & 139.20 & 141.52 & 146.12 & 122.54 \\
\hline Mean & 72.37 & 96.67 & 156.72 & 163.36 & & 75.07 & 165.03 & 167.78 & 173.23 & \\
\hline L.S.D at $5 \%$ & \multicolumn{2}{|c|}{ A: 3.64} & B: 2.11 & \multicolumn{2}{|c|}{ AB: 4.22} & \multicolumn{2}{|c|}{$\mathrm{A}: 4.01$} & B: 2.32 & \multicolumn{2}{|c|}{ AB: 4.64} \\
\hline
\end{tabular}

while $\mathrm{N}_{1} \mathrm{P}_{1} \mathrm{~K}_{1}(125 \mathrm{~kg} / \mathrm{fed})$ came in the third class in both seasons. These three levels of mineral fertilization increased fresh weight over control treatment by $104.48,145.52$ and $141.43 \%$ in the first season and by 106.03 , 113.48 and $142.63 \%$ in the second one, respectively. Also, these three mineral fertilization treatments significantly increased herb dry weight as compared to control in both seasons. The heaviest dry weights were obtained by the highest level of $\mathrm{N}_{3} \mathrm{P}_{3} \mathrm{~K}_{3}$ as recorded 163.36 and 173.23 in the first and second seasons, respectively.

In harmony with our results were those noted on guar by El-Barkouky et al. (1980), Meawad et al. (1991), Tewfike (2000), Abo El-Ezz (2019) and Abd Allah et al. (2020).

Concerning the effect of number of cuts on herb fresh and dry weights/plant, it could be observed that both herb fresh and dry weights/plant were significantly decreased by increasing number of cuts in both seasons compared with uncut plants.

Our results were in the line with those observed by Omer et al. (1993) on guar plant; Tabacco et al. (2002) on lucerne; Moniruzzaman et al. (2008) on kangkong plant; Tehlan and Thakral (2008), Moniruzzaman and Rahman (2015), Abd ElAzim and Waleed (2016), Singh et al. (2017) and Bhapkar et al. (2019) on coriander; Foidl et al. (2011), Lawal et al. (2015) and Ibrahim (2017) on Moringa oleifera; Sarkar et al. (2014) on Ipomoea reptans and Narayan et al. (2018) on palak (Beta vulgaris var. Bangalensis) plant.

The interaction between main and subplot treatments $(\mathrm{A} \times \mathrm{B})$ was significant for shoot fresh and dry weights/plant in both experimental seasons as clearly shown in Table (2). The heaviest weights were obtained by fertilizing guar plants by mineral fertilization treatment $\mathrm{N}_{3} \mathrm{P}_{3} \mathrm{~K}_{3}(500 \mathrm{~kg} / \mathrm{fed})$ without cut $\left(\mathrm{NC}_{0}\right)$ in both seasons $(850.16$ and $859.20 \mathrm{~g}$, respectively for shoot fresh weight and 186.06 and $197.30 \mathrm{~g}$, respectively for shoot dry weight.

\section{DISCUSSION}

Supplying plants with mineral fertilization formulations of $\mathrm{N}_{1} \mathrm{P}_{1} \mathrm{~K}_{1}$ (125 $\mathrm{kg} / \mathrm{fed}), \mathrm{N}_{2} \mathrm{P}_{2} \mathrm{~K}_{2}(250 \mathrm{~kg} / \mathrm{fed})$ and $\mathrm{N}_{3} \mathrm{P}_{3} \mathrm{~K}_{3}$ $(500 \mathrm{~kg} / \mathrm{fed})$ led to an increase in all vegetative growth traits (plant height $(\mathrm{cm})$, number of branches/plant, herb fresh and dry weights/plant (g)). These results reflected the enhancing role of NPK fertilization. Nitrogen is an indispensable elementary constituent of numerous organic compounds of general importance, amino acids, proteins, nucleic acids and compounds of secondary plant metabolism such as the alkaloids. 
Higher plants are major contributors to the large amount of $\mathrm{N}$ which is continuously being converted from the inorganic to the organic form. The exact function of potassium in the energy conversion process is not yet totally understood. Although, it is documented that potassium is involved in metabolic reactions including those of energy (ATP), synthesis and energy transfer (Mengel and Kirkby, 2001). The improvement impact of NPK on plant growth and productivity may be due to the role of nitrogen on chlorophyll, enzymes and proteins synthesis; and the role of phosphorus on root growth development, phosphor-proteins and phospho-lipids formation as well as the role of potassium on promotion of enzymes activity and enhancing the translocation of assimilates (EL-Desuki et al., 2006).

From the previous physiological and biological studies, it might be concluded that NPK fertilizers had positive effects on vegetative growth. While increasing number of cuts led to good branches. The reduction of plant height might be due to the apical dominance which causes the development of lateral buds, ultimately increasing the number of shoots (Sarkar et al., 2014).

\section{REFERENCES}

Abd Allah, A.M.; Hassan, H.H.M. and Awad, M.M. (2020). Forage productivity, competition indices and economics of forage millet and guar as affected by intercropping pattern and nitrogen fertilizer under sandy soil conditions. Journal of Plant Production Sciences, 9(1):47-59.

Abd El-Azim, A. and Waleed, M. (2016). Effect of compost and number of cuttings on productivity of Coriandrum sativum L. under Sinai conditions. Egyptian Journal of Desert Research, 66(1):57-68.

Abo El-Ezz, S. (2019). Translocation of some elements in guar plant (Cyamopsis tetragonoloba L.) as affected by NPKfertilization and compost of town refuse.
Journal of Soil Sciences and Agricultural Engineering, 10(3):173-177.

Akash, M.W. and Saoub, H.M. (2000). Forage yield of three Sudangrass varieties as influenced by seeding rate and cutting frequency. Dirasat, Agricultural Sciences, 27(2):158-164.

Ali, S.M. (1990). Growth and Yield of Guar (Cyamopsis tetragonoloba, L. Taub.) as Influenced By Sowing Date and Fertilization. M.Sc. Thesis, Fac. Agric., Zagazig University, Egypt, 88 p.

Ansa, J.E.O. and Garjila, Y.A. (2019). Effect of cutting frequency on forage growth and yield in elephant grass in the southern rainforest of Nigeria. International Journal of Environmental and Agriculture Research, 5(7):1-5.

Ayub, M.; Khalid, M.; Tariq, M.; Nadeem, A.M. and Naeem, M. (2011). Effect of different seeding densities and nitrogen levels on growth, forage yield and quality attributes of cluster bean (Cyamoposis tetragonoloba Tuab.). Journal of Agricultural Technology, 7(5):14091416.

Bhapkar, P.B.; Sharma, H.D.; Negi, S.; Pundir, D.; Sharma, V.; Kapil, M. and Reddy, S. (2019). Effect of cutting and intra row spacing on yield and phenotypical attributes of coriander (Coriandrum sativum L.). Int. J. Curr. Microbiol. App. Sci, 8(9):693-698.

El-Barkouky, M.; Mansour, B.M. and Khater, M.R. (1980). Effect of different rates of fertilization on yield and guaran content in guar plants. Bull. No. 35 ElAzhar University, Egypt.

El-Desuki, M.; Mahmoud, A.R. and Hafiz, M.M. (2006). Response of onion plants to minerals and bio-fertilizers application. Research Journal of Agriculture and Biological Sciences, 2(6):292-298.

Foidl, N.; Mayorga, L.; Vásquez, W.; Murqueitio, E.; Osorio, H.; Sanchez, M.D. and Speedy, A. (2011). Utilización 
del marango (Moringa oleifera) como forraje fresco para ganado. FAO animal production and health paper, 341-350.

Gendy, A.S.; Said-Al Ahl, H.A.; Mahmoud, A.A. and Mohamed, H.F. (2013). Effect of nitrogen sources, bio-fertilizers and their interaction on the growth, seed yield and chemical composition of guar plants. Life Science Journal, 10(3):389-402.

Giambalvo, D.; Amato, G.; and Stringi, L. (2011). Effects of stubble height and cutting frequency on regrowth of berseem clover in a Mediterranean semiarid environment. Crop Science, 51(4):1808-1814.

Gillett, J.B. (1958). Indigofera (Microcharis) in tropical Africa with the related genera Cyamopsis and Rhynchotropis. Kew Bull. Add., 1:1-166.

Ibrahim, O.R.A. (2017). Effect of Some Agricultural Treatments on Growth, Yield and Chemical Constituents of Moringa Seedlings. M.Sc. Thesis, Fac. Agric., Al-Azhar University (Assiut branch), Egypt, 162 p.

Jackson, M.L. (1973). Soil Chemical Analysis. Prentice-Hall of India Private Ltd. M-97, New Delhi, India, 498 p.

Kamel, N.M. (2009). Physiological Studies on Some Medicinal and Aromatic Plants. M.Sc. Thesis, Fac. Agric., Minia University, Egypt, 122 p.

Lawal, B.A.; Olawepo, T.F.; Asaolu, V.O.; Akanbi, W.B.; Jolaoso, M.A. and Ojo, A.M. (2015). Effect of different methods of establishment on growth and biomass yield of moringa (Moringa oleifera, Lam). International Journal of Agriculture and Crop Sciences, 8(4):650653.

Mahdy, A.Y. and El-Said, M.A.A. (2017). Effect of intercropping and cutting date for guar on soybean yield. International Journal of Agriculture and Economic Development, 5(2):82-102.
Meawad, A.A.; Awad, A.E.; Khalil, A. (1991). The combined effects of Pfertilization and gibberellin as well as daminozide treatments on: 1- Growth and guaran content of guar plants. Zagazig J. Agric. Res., 18 (6): 2155-2165.

Mengel, K. and Kirkby, E. (2001). Principles of Plant Nutrition, $5^{\text {th }}$ Edition. Kluwer Academic Publishers \& Springer, Dordrecht, Netherlands, 849 p.

Mohamed, A.M.S. (2009). Physiological studies on guar plants. M.Sc. Thesis, Fac. Agric., Minia University, Egypt, 98 p.

Moniruzzaman, M. and Rahman, M.M. (2015). Effect of nitrogen level and leaf cutting frequency on foliage and seed yields of coriander. Bangladesh Journal of Agricultural Research, 40(1):53-60.

Moniruzzaman, M.; Mozumder, S.N.; Hassan, J. and Quamruzzaman, A.K.M. (2008). Effects of nitrogen levels and frequency of foliage cuttings on the production of foliage and seed of kangkong. Bangabandhu Sheikh Mujibur Rahman Agricultural University, 12(1):85-93.

MSTAT-C (1986). A microcomputer program for the design management and analysis of agronomic research experiments (Version 4), Michigan State Univ., USA.

Narayan, S.; Malik, A.; Makhdoomi, M.I.; Nabi, A.; Hussain, K. and Khan, F.A. (2018). Influence of date of sowing and number of cuttings on leaf yield and quality of seed in palak (Beta vulgaris var. Bangalensis). Journal of Experimental Agriculture International, 24(3):1-4.

Nayak, P.K. and Maji, S. (2018). Response of nutrient and cutting management for quality and green yield of Palak (Beta vulgaris var. bengalensis). Journal of Crop and Weed, 14(1):126-129.

Omar, M.D. (2005). Effect of Some Agricultural Treatments on Growth, Yield and Active Ingredient of Guar 


\section{M.A.H. Abdou et al.}

(Cyamopsis tetragonoloba, L.) Plants. Ph.D. Thesis, Fac. Agric., Minia University, Egypt, 210 p.

Omer, E.A.; Fattah, A.; Razin, M. and Ahmed, S.S. (1993). Effect of cutting, phosphorus and potassium fertilization on guar plant (Cyamopsis tetragonoloba) in newly reclaimed soil in Egypt. Plant Foods for Human Nutrition, 44(3):277284.

Pimonov, K.I.; Solodovnikov, A.P.; Belogolovtsev, V.P.; Gusakova, N.N., and Poletaev, I.S. (2021). The influence of foliar fertilization on the productive of Cyamopsis tetragonoloba (L.) Taub. cultivated on ordinary chernozem. In IOP Conference Series: Earth and Environmental Science, 723 (2): 022073.

Rana, S.C.; Pandita, V.K. and Sirohi, S. (2015). Influence of spacing and number of leaf cuttings on seed yield in fenugreek. Legume Research - An International Journal, 38(6):858-860.

Razin, A.M. (1991). Response of guar to foliar fertilizers (Irral) in the new reclaimed soils. Minia J. Agric. Res. \& Dev., 13(2):726-735.

Salah El-Deen, R.M. (1997). Effect of Some Growth Regulators and Nitrogen Sources on Growth and Chemical Composition of Guar Plants. M.Sc. Thesis, Fac. Agric., Minia University, Egypt, 99 p.

Salama, H. and Nawar, A. (2016). Studying the nutritive profile of guar [Cyamopsis tetragonoloba (L.) Taub.] harvested at different ages and its potential as a summer forage legume in Egypt. Egyptian Journal of Agronomy, 38(3):559-568.

Sarkar, R.K.; Jana, J.C. and Datta, S. (2014). Effect of cutting frequencies and nitrogen levels on growth, green and seed yield and quality of water spinach (Ipomoea reptans Poir.). Journal of Applied and Natural Science, 6(2):545-551.

Seerangan, G.; Sha, K. and Muraleedharan, A. (2019). Effect of organic inputs and inorganic nutrients on growth and yield of cluster bean (Cyamopsis

tetragonoloba (L.) Taub. Journal of Pharmacognosy and Phytochemistry, 2:580-581.

Simon, J.C.; Jacquet, A.; Decau, M.L.; Goulas, E. and Le Dily, F. (2003). Influence of cutting frequency on the morphology and the $\mathrm{C}$ and $\mathrm{N}$ reserve status of two cultivars of white clover (Trifolium repens L.). European Journal of Agronomy, 20(4):341-350.

Singh, P.; Mor, V.S.; Khan, M. and Kumar, S. (2017). Effect of foliage cuttings on seed yield and quality of coriander (Coriandrum sativum L.). Advances in Research, 10(4):1-9.

Sortino, O. and Gresta, F. (2007). Growth and yield performance of five guar cultivars in a Mediterranean environment. Italian Journal of Agronomy, 2(4):359-364.

Sowiński, J. and Szydełko, E. (2011). Growth rate and yields of a sorghumsudangrass hybrid variety grown on a light and a medium-heavy soil as affected by cutting management and seeding rate. Polish Journal of Agronomy, 4:23-28.

Tabacco, E.; Borreani, G.; Odoardi, M. and Reyneri, A. (2002). Effect of cutting frequency on dry matter yield and quality of lucerne (Medicago sativa L.) in the Po Valley. Italian Journal of Agronomy, 6(1):27-34

Tehlan, S.K. and Thakral, K.K. (2011). Effect of different levels of nitrogen and leaf cutting on leaf and seed yield of coriander (Coriandrum sativum). Journal of Spices and Aromatic crops, 17(2):180182.

Tewfike, T.A. (2000). Effect of dual biofertilization, biogas manure and mineral fertilizer on guar plants [Cyamopsis tetragonoloba (L.) Taub.] J. Agric. Sci., Mansoura Univ., 25:64816492. 
Tufail, M.S.; Krebs, G.L.; Southwell, A.; Piltz, J.W.; Norton, M.R. and Wynn, P.C. (2020). Enhancing performance of berseem clover genotypes with better harvesting management through farmers' participatory research at smallholder farms in Punjab. Scientific Reports, 10(1): $1-12$.

Ventroni, L.M.; Volenec, J.J. and Cangiano, C.A. (2010). Fall dormancy and cutting frequency impact on alfalfa yield and yield components. Field Crops Research, 119(2-3):252-259.

\footnotetext{
تأثثير التسميد المعدني وعدد مرات الحش علي نمو وإنتاجية نبات الجوار

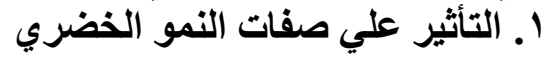$$
\text { محمود عبدالهادي حسن، فاروق صلاح الدين بدران، أحمد عبدالمنعم السيد، أسامه راشد عبدالسلام إبر اهيم }
$$

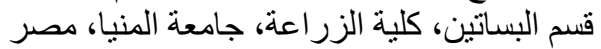

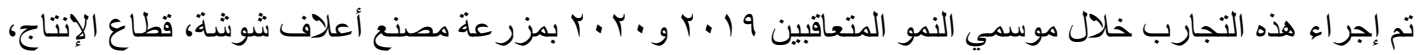

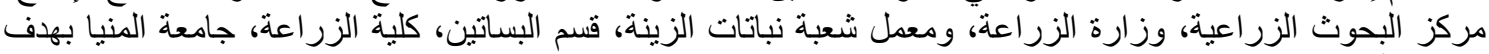

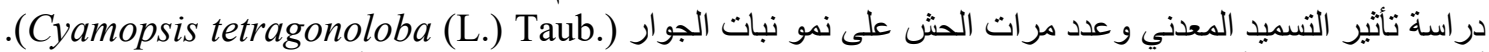

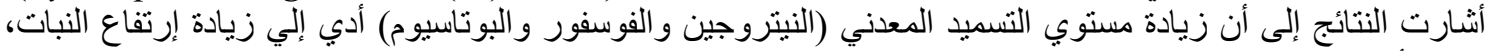

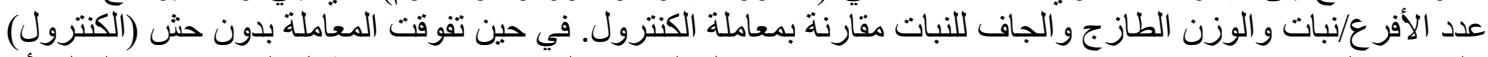

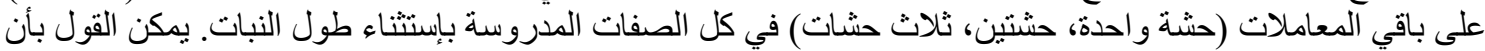

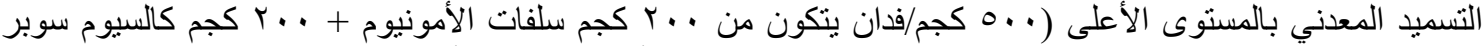

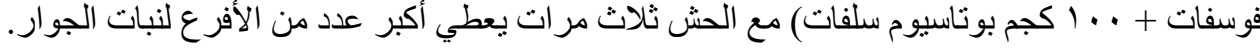

